Article

\title{
Entering the Mindset of Violent Religious Activists
}

\section{Mark Juergensmeyer}

Department of Sociology and Global Studies, University of California, Santa Barbara, Santa Barbara, CA 93106, USA; E-Mail: juergens@global.ucsb.edu

Academic Editor: John L. Esposito

Received: 30 June 2015 / Accepted: 16 July 2015 / Published: 23 July 2015

\begin{abstract}
How can one enter the mindset of religious activists whose worldview and values are different from one's own? This is the challenge for analyzing contemporary violent religious movements and individuals around the world. This essay suggests guidelines, based on the author's interview experience, for entering religious minds through informative encounters, relational knowledge, bracketing assumptions, and constructing a view of the whole.
\end{abstract}

Keywords: religious violence; terrorism; methodology; interviews; social analysis

\section{Introduction}

How can we enter into the mindset of religious activists, especially those with views that are quite different from our own? The problem is confounded when confronted with those who are engaged in acts of violence that appear to be justified by faith. This is the challenge for anyone who is trying to make sense of the religious-related violence that seems to be epidemic at the turn of the 21 st century. One can explain the rise of the Islamic State in Iraq and Syria, Jewish extremism, or the outbreak of Christian Islamophobia by external factors, examining the political and social factors that lie behind them. Another option is that one can set them with the contexts of broad historical trends and relate them to similar phenomena at other times and places. However, as useful as these scholarly pursuits might be, these analyses seldom explain what role religion plays, and it does not help us understand the passion and commitment with which the activists are dedicated to their cause. For this we have to go inside the mindset of the activists themselves. 
The benefit of doing this is that we can discover areas of understanding that we had not thought of before, and debunk assumptions and misconceptions about motives. Take the issue of religious beliefs, for instance. There is a common assumption among many observers that religious beliefs - and specifically tenets of religious scripture - motivate activists to undertake acts of violence. Whether it is the teachings of the Qur'an or the incendiary verses of the Hebrew Bible (the Old Testament), religious ideas and beliefs are often thought to be the problem. My own interviews, however, indicate that very few religiously-related activists frame their motivations in scriptural or theological terms. Most are woefully ignorant about the textual and intellectual aspects of their traditions. Instead, they talk about the defense of their community and their faith in general, and the threat of particular groups, including secular politicians, in particular. Religious beliefs and traditions are a part of their worldview, but only a part of it, even though it may be the vocabulary through which other social and political issues are enunciated. However, in order to discover this perspective of religion-related activists, one has to see the world as they see it. Entering the mindset of activists can open doors to understanding.

How can this be done? This is the challenge for anyone trying to make sense of people and groups that are different than themselves. It is a problem for textual and historical scholars, as well as those applying contemporary social and anthropological approaches. In addition, it is the question that I have had to face in a series of interviews with radical religious activists in a variety of religious traditions and locales over the last twenty years. In my own case, the interviews involved leaders of the Palestinian Hamas movement in Gaza, an activist in prison who was associated with the al Qaeda-related 1993 bombing of the World Trade Center, a Lutheran pastor convicted of bombing abortion clinics on the East Coast of the United States, Catholic and Protestant leaders during the "troubles" in Northern Ireland, Sikh separatists in India, Muslim insurgents in Iraq, and Buddhist activists in Sri Lanka, Myanmar, and Japan [1].

Despite the diversity of these cases, there were some common threads that tied together these activists from varied cultures and regions. All of them had supported or participated in public acts of aggression or violence, including acts that we would regard as terrorism. None of them regarded themselves as terrorists, however. Mahmud Abouhalima, the jihadi activist associated with the 1993 World Trade Center bombing, whom I interviewed in the Lompoc Federal Penitentiary in California, made a clear conceptual difference between terrorists - by which he meant people who simply wanted to kill indiscriminately - and soldiers who were fighting a defensive war. The latter described himself and his actions, and the same can be said of all of the other activists with whom I spoke. They all regarded themselves as soldiers in a grand battle, a cosmic war between right and wrong, truth and evil. That moral element of their vision is where religion came in: all of these activists were fighting for social or political reasons but they framed their efforts in religious terms. Though religion was only part of their stories, it was an important part, and it was the way in which many of them characterized their struggle.

Finally they all had in common one other thing: they wanted to talk with me. In all cases I had contacted them in advance and they had willingly — in many cases eagerly_agreed to the interviews, knowing that I would use the material in the books I was writing. Abouhalima insisted that my interviews with him be tape recorded to insure accuracy. A similar concern was expressed by a Buddhist monk in Myanmar, Ashin Wirathu, who Time magazine had labelled "the face of Buddhist 
terror" for his role in allegedly advocating violence against Muslims in his country [2]. Wirathu insisted on seeing the transcript of my interview before he would agree to my using it publicly. In fact, in all cases I sent transcripts or extensive notes of the interviews to the persons with whom I spoke. I wanted to make sure that I had accurately recorded their words and appropriately interpreted their meanings. This was a potentially dangerous approach, since any of them could deny that they had said such things and prohibit me from using the interview material. Fortunately none did, though the member of the Japanese movement, Aum Shinrikyo, whom I had interviewed in Tokyo was afraid that members of the movement would find him and punish him for what he had said. Though many leaders of the movement were in jail after their use of sarin gas to create a terrorist attack on the Tokyo subways, others were re-establishing the movement under a new name, Aleph. For that reason, I used a pseudonym for his name and obscured any information that might lead to his identity. Everyone else was agreeable to my using their interviews as I had recorded or made notes of them, and Abouhalima followed up the interviews with a number of letters to me adding additional information and ideas, some of which I used in the book.

However, all of this is preliminary to what I actually did when I interviewed them. How did I go about these meetings, and what were the salient methodological principles? My approach was based on established patterns of social and anthropological inquiry, adapted to the challenges of confronting world views quite different from my own. In general, I followed a distinctive approach that had several formative characteristics that in a general way replicated the guidelines that the Danish political scientist, Mona Sheikh, and I have formulated in our essay on how to do what we have termed epistemic worldview analysis [2,3]. These principles can apply to a variety of scholarly endeavors, including those where the subjects cannot easily be interviewed, including studies that are based on the analysis of a subject's writings and transcribed interviews, as well as textual and historical analysis. They apply to any attempt to enter into a mindset different from one's own, though in the case of religious extremists the challenge is particularly daunting.

\section{Informative Encounters}

The first task is to try to enter into the mindset of the subjects through direct engagement. Interviews provide that opportunity, of course, but so do analyses of the subjects' writings and transcribed interviews, and first-person narratives about them. Historical studies can bring to life figures who are centuries old in vivid detail. In my case, however, I was able to actually encounter my subjects through interviews. Then the issue was how to conduct these in a way that was most effective.

The problem with many scholarly interviews is that they follow a script of questions that are predetermined and that therefore limit the scope of what can be discovered. Even the best advice in the literature on doing interviews for qualitative research is goal-oriented, and suggests that the interviewer have specific subjects to pursue [4-6]. Since my motive was to get inside the mindset of the activists, I had to abandon the comforting script of questions, and engage in a more open-ended encounter. Hence most of my interviews appeared to be conversations. When I was in a mosque in Baghdad, talking with one of the leaders of the Association of Muslim Clergy of al Anbar province in Iraq, it may have seemed like were just chatting. To the casual observer, and mostly likely from the point of view of the subjects with whom I was speaking, there was nothing directive about the 
conversation. It was not random, however, since I had in mind areas of inquiry (though not specific subjects) that I wanted to discuss. However, I never posed questions in a didactic way.

Though one could conclude that these conversations were efforts at getting information through understanding the subject's point of view, they were not scientific surveys. At one point in my academic career I thought that that was indeed what social scientists were supposed to do. As a beginning graduate student doing field work in village India, I was determined to conduct a survey analysis among the lower caste workers of a Punjab village. To be properly scientific I devised a 60 -question interview. It floundered with question \#1 and totally collapsed with question \#2. The first question was simple enough - "what is your name"? Yet among the lower caste members of North Indian villages they often had different names for different occasions: caste names, occupation names, religious names, and village names. The second question was "what is your religion"? This term, easy to understand in the West, could not be directly translated in Panjabi, Hindi, or any other Indian language. The idea of one word that corresponds to a whole range of religious activity and identity did not exist. There was dharma for religious law, qaum for a religious community or nation, mazhab for religious beliefs, and panth for a religious fellowship ([7], pp. 1-7). Just what, the villagers wanted to know, did I have I mind?

The problem with social surveys is that they assume that we know what to ask before we ask the question. Instead, I began to experiment in an interactive approach, what one might call "informative encounters". These encounters were conversational in that they were not directive at the outset, though they were aimed at getting an understanding of how the subject viewed the world. In particular, I was concerned with the role of religious ideas and identity in the way that they framed political issues, and their justification for the use of violence in social conflict. However, rather than asking that directly, I usually began with a question asking them to provide some autobiographical background, to tell me how they came to their involvement in social activism. These accounts would often lead naturally to follow-up questions about religion, politics, and violence that probed the areas in which I was interested, but also illumined their view of the world and the way that these issues fit into the larger scheme of their personal concerns.

\section{Relational Knowledge}

Though I had a general idea of the areas of interest that I wanted to probe in my interviews, as I have said, I did not have a list of questions. When I was in Myanmar in September 2014, talking with the activist Buddhist monk, Wirathu, I began with questions about his involvement in the monastery and his interest in social issues [8]. When he said that Buddhists should be engaged in society, this naturally led to questions about how they should do it and whether violence is ever justified. "Buddhism is nonviolent", he would insist repeatedly. Clearly this line of discussion was closed, from his point of view. It did allow me, however, to reframe the question from his point of view. If Buddhism needed to be engaged, and needed to defend itself, I asked him, from what and where were the threats coming? Immediately Wirathu snapped back that Muslim extremists were the threat, and all that was distinctive about Burmese Buddhism was in peril. This allowed us to move into the area of Buddhist-Muslim relations and to ask him the degree to which Buddhists were justified in defending themselves - even, if necessary, defending themselves in a situation that might lead to violence. 
Wirathu allowed for Buddhist violence in this context, though the subject would never have come up if I were not able to switch the direction of the conversation and reframe my questions depending on his previous responses.

This is not just a matter of being adroit in one's line of questioning, but also a matter of learning from what was said. It requires one to change ideas about what to ask depending on previous answers, and to let the conversations move in whatever direction seems appropriate. This is neither inductive nor deductive reasoning. Inductive reasoning assumes that one has a general idea or principle from which one makes sense of particular data. Deductive reasoning tries to build up the larger picture from accumulating particular information. The approach that I use might be called "relational reasoning", a form of understanding that emerges from the give and take of points of view in an interactive conversation. It is relational in that what is discovered depends upon the relationship between the conversation partners, with questions changing in response to the way previous questions have been answered. It is reasoning in that it aims at understanding the point of view of the subject, trying to make sense of the logic that informs a person's actions, including especially those actions that seem so inappropriate and unjustified in normal relationships, acts of violence.

\section{Bracketing Assumptions}

The point of these conversations is to try to enter into the mindset of the interview subjects, to understand as best as possible how they see the world. This means that as much as possible we should try to bracket our own judgments about what is being said. It is a double bracketing in fact: we should try to reserve making value judgments, at least publicly, about the truth or falsity of what they are saying, and to avoid making judgments about the truth or falsity of our own points of view (though needless to say, we think that we are always right). Sometimes both of these are difficult, especially when the issue at hand is the moral sanction for violence, or the unequal treatment of other people on the basis of their ethnicity, religion, or gender. Yet for the sake of the interviews we should keep our judgment about these matters at bay. There will be ample opportunity in the future to reflect on the conversation and condemn the subjects, if we feel that condemnation is warranted.

However, in the heat of a conversation it is not easy to stay silent. I remember a conversation with the Israeli activist, Rabbi Meir Kahane, a cheerful character with a Brooklyn accent, who passed over the territorial claims of Palestinians as if they were trivial matters. From his point of view they were; after all, he believed that the Israeli claims over Eretz Israel - greater Israel, including the Palestinian West Bank of the Jordan River-were essential in order to lay the foundations for the coming of the Messiah. This is heady stuff in Jewish history, so it is understandable that if he fervently believed that the greatest moment of biblical prophecy was about to be fulfilled, territorial claims could seem to be a minor matter. Still, it was not a minor matter to Palestinians who were uprooted from their homes and who had their own claims to the region that Kahane thought was essential for Israel to occupy. "This is biblical land", Kahane told me, implying that the Palestinians did not belong there; "they should just leave", he said. It took all of my sense of self-control to keep from arguing with him, though I knew that there would have been no point to it if I did, his mind was closed on the subject. In a similar way, the Buddhist monk Wirathu in Myanmar was convinced that Muslims in his country were a corrosive force that would undermine Burmese culture and there would be no way to convince him otherwise. 
My discussions with the Christian militant, Rev Michael Bray, probably involved the most give-and-take, since he was interested in talking about theology, and I knew the works of Reinhold Niebuhr and Dietrich Bonhoeffer that he admired. I clarified my own interpretations of their work, and Bray observed that they were different than his, which did not surprise him. He had already categorized me as a liberal Christian who would see scripture and theology differently from his point of view. So there, a tacit agreement to disagree, and there was no need to argue with him, he already knew my position. What I wanted to understand was his.

Perhaps the closest I came to getting into an argument in my interviewers was with the World Trade Center bomber, Mahmud Abouhalima. At one point in our discussion he was trying to make a distinction between his world of faith and the secular world around him. He pointed to me, and asserted that "you secularists" had no way of knowing what it was like to try to live faithfully in a secular society. I instinctively reacted, since I was raised in a churchgoing household, attended seminary before graduate school, and continued to be a regular member of a Protestant Christian congregation. Still, my protestations were brushed off by Abouhalima who insisted, "no, Mr. Mark, you are a secularist". And then he added, "I know your world, I've lived in it; but you haven't lived in mine" ([1], p. 70).

Abouhalima was right, in fact. My religiosity was one that was comfortable with the secular, multicultural modernity of the contemporary West. This was the world that he was projected into after leaving Afghanistan where he had been a part of the Mujahidin militia fighting the Soviet-backed government, and before that he was in his native Egypt, where he was a member of an extremist offshoot of the Muslim Brotherhood, the Gamaa i-Islamiya. The world of New Jersey was certainly different, as was Germany where he lived for some years after leaving Egypt. So he did know my world. Additionally, it is also true that I did not really know his, even though I lived for several years in India and have spent a considerable amount of time in Muslim-majority countries. However, I have never really been out of my secular modernist element, and Abouhalima was right to remind me that I did not know his world as he knew mine. That did not mean that I condoned his interpretation of the commandments of his faith, not did it alter my judgment that he was motivated as much by a kind of macho soldier-of-war adventurism as he was by piety. Still his point was well made, and I had to make the attempt to see the world as he saw it_or at least the way he wanted me to think that he saw it.

\section{Entering Their Worldview}

This brings up another point - was I really probing into his mindset, or was I simply uncovering a version of himself that he wanted to sell? The point of my informed conversations was to let the subjects reveal their perspective on the world around them, which is why I was careful not to dominate the conversations. One might object that this open-ended approach to interviews allowed the subjects to control the situation. Moreover, it would allow them to present themselves exactly as they would like to be presented. Especially since they were eager to talk with me, as I just mentioned, would they not be eager to present a carefully choreographed image of themselves for my sake?

The answer to this question is yes, most likely. However, even that is an interesting datum-it is useful to know how they would like to have themselves presented, and to contrast that with other information that I had gathered about their past and their social and political involvements. In every 
case I did not come to an interview cold, knowing nothing about the subjects; quite the opposite, I tried to learn as much as I could about what they had said and written, and how they had been perceived and described by others, before interviewing them. I kept all of this knowledge in the back of my mind as a kind of corrective to what they might be saying and as a reminder to push them in certain directions.

In the case of Abouhalima, for instance, he never admitted to being involved in the attack on the World Trade Center even though he was tried and convicted in a US court for exactly that crime. Still, he was hoping to get out on appeal, and would not say anything that would implicate him directly in that incident. But in the course of the conversation I found that he was quite willing to talk about the Oklahoma City Federal Building bombing - after all, no one had implicated him in that crime, nor was there any possibility that he could have been involved in it since he was in prison at the time. This allowed me to ask him why some people, whoever they might be, would bomb buildings. He assured me that it was for a reason-Timothy McVeigh and his allies were not just bombing things for the sake of bombing them - they were trying to send a message. "What kind of message", I asked him, knowing that his answer would apply to his own convicted participation in the World Trade Center bombing as well as to McVeigh's Oklahoma City Federal Building attack. "They wanted to show you that your government is the enemy", he answered. He paused, and then added, "and now you know".

These are some of the guidelines that might be followed in attempting what Mona Sheikh and I have called "epistemic worldview analysis". They do not amount to a methodology, in the sense of a prescribed analytic approach. Rather they are general principles that are relevant in a variety of analytic situations-if one is involved in textual research, social survey studies or a more anthropological approach of entering into case studies. The greater involvement with the subjects of the study the better, though in the case of historical studies often the only evidence one has of their ways of thinking is in letters or writings or in others' commentary about them.

\section{Conclusions}

The degree to which scholars will want to immerse themselves in the milieu of their subjects depends in part on the purpose of the project: whether it is a broad comparative overview or a more intensive case study. Though I have done intensive case studies in other books, my project in Terror in the Mind of God was a broad comparative analysis of disparate activists in differing cultures and regions [1]. There I attempted to find patterns in their ways of thinking and to identify some similarities in their understanding of the relation of religious images and ideas to contemporary social and political situations. Of course it would have been a more thorough study if I had known the languages of all of my subjects-Arabic, Hebrew, Burmese and Japanese, as well as Hindi and Panjabi. As it was, I was reliant on translators for many of the conversations. It would have been a deeper study if I had spent more time in each locale, came to know others within their circle, and relied not on one or two interviews but on many. Yet this would have been a different book, or more likely a series of books. My purpose was to have comparative snapshots of a range of religious activists, and I feel fortunate to have had the remarkable conversations that I had. Though Abouhalima may still not believe it, I think that I was able to penetrate into his world and the worldviews of the many others with whom I spoke, for at least a bit, and that opening illumined much about why he and others did what they did, and why their worlds have been so very hard for us to understand. 


\section{Conflicts of Interest}

The author declares no conflict of interest.

\section{References}

1. Juergensmeyer, Mark. Terror in the Mind of God: The Global Rise of Religious Violence, 3rd ed. Berkeley: University of California Press, 2003.

2. Juergensmeyer, Mark, and Mona Kanwal Sheikh, eds. Entering Religious Minds. Berkeley: University of California Press, 2015, submitted for publication.

3. Juergensmeyer, Mark, and Mona Kanwal Sheikh. "A Sociotheological Approach to Understanding Religious Violence." In The Oxford Handbook of Religion and Violence. Edited by Mark Juergensmeyer, Margo Kitts and Michael Jerryson. New York: Oxford University Press, 2013.

4. Brinkmann, Svend, and Steinar Kvale. InterViews: Learning the Craft of Qualitative Research Interviewing. London: Sage Publications, 2014.

5. Van Maanen, John. Tales of the Field: On Writing Ethnography, 2nd ed. Chicago: University of Chicago Press, 2011.

6. Weiss, Robert. Learning from Strangers: The Art and Method of Qualitative Interview Studies. New York: The Free Press, 1995.

7. Juergensmeyer, Mark. "Chatting with Myanmar's Buddhist 'Terrorist'." Religion Dispatches, 17 February 2015. Available online: http://religiondispatches.org/chatting-with-myanmars-buddhistterrorist/ (accessed on 10 March 2015).

8. Juergensmeyer, Mark. Religion as Social Vision: The Movement against Untouchability in 20th Century Punjab. Berkeley: University of California Press, 1982.

(C) 2015 by the author; licensee MDPI, Basel, Switzerland. This article is an open access article distributed under the terms and conditions of the Creative Commons Attribution license (http://creativecommons.org/licenses/by/4.0/). 